Article

\title{
Soil Water Surplus in Salado River Basin and Its Variability during the Last Forty Years (Buenos Aires Province, Argentina)
}

\author{
Olga Eugenia Scarpati ${ }^{1,2, *}$, Liliana Beatriz Spescha ${ }^{3}$, Juan Alberto Forte Lay ${ }^{1}$ \\ and Alberto Daniel Capriolo ${ }^{1}$
}

1 National Council of Scientific and Technical Research, Avenue Rivadavia 5485, Buenos Aires, 1424, Argentina; E-Mails: jaflay2004@yahoo.com.ar (J.A.F.L.);

albertocapriolo@yahoo.com.ar (A.D.C.)

2 Geography Department, Humanities and Education Sciences Faculty, National University of La Plata, 48 Street, La Plata, Buenos Aires, 1900, Argentina

3 Faculty of Agronomy, University of Buenos Aires, Avenue San Martín 4453, Buenos Aires, 1417, Argentina; E-Mail: spescha@agro.uba.ar

* Author to whom correspondence should be addressed; E-Mail: olgascarpati@ yahoo.com.ar.

Received: 11 November 2010 / Accepted: 30 December 2010 / Published: 18 January 2011

\begin{abstract}
Soil water surplus and deficit occur frequently in Buenos Aires province in Argentina. This paper analyses the soil water surplus in a sub-area, the Salado River basin, in the period 1968-2008. This basin is divided in seven drainage areas, delimitated according to the National Water Resources. The series of soil water surplus data were adjusted by means of the theoretical normal cubic-root probability distribution, and the mean areal soil water surplus value of $300 \mathrm{~mm}$ was considered as a threshold above which floods can cause severe damage. An increase in the frequency of extreme events and in their tendency exists during the recent years, coherent with the increase of precipitation recorded in the region. The statistical significance of the results was assessed using the Mann Kendall and MAKESENS tests. The results showed a relevant temporal variability, but did not show significant tendencies.
\end{abstract}

Keywords: Salado river basin; water budget; flood risk 


\section{Introduction}

The Salado River is located in the Buenos Aires (hereafter, BA) province, in eastern Argentina, and flows eastwards to the Atlantic Ocean. Its basin is an almost flat region with a mean gradient of $0.25 \%$ from west to east, and covers a wide region known as the Pampas Plain or Pampean flatlands. The basin is roughly rectangular, and its coordinate margins are: $34^{\circ} 30^{\prime} \mathrm{S}$ and $38^{\circ} 10^{\prime} \mathrm{S}$ for the latitude, and $63^{\circ} 23^{\prime} \mathrm{W}$ and $56^{\circ} 41^{\prime} \mathrm{W}$ for the longitude. In recent decades, there were several episodes of soil water surplus (sws, hereafter), caused mainly by intense rainfall [1-3].

The goal of this paper is to analyze the evolution of annual sws in the period 1968-2008, considering seven drainage areas corresponding to the Salado River basin (BA province, Argentina), in order to determine the areas with the highest frequencies of occurrence.

The BA province is a large plain with an elevation of less than $300 \mathrm{~m}$. The Tandilia and Ventania hills, located in the southern part of the region, reach $520 \mathrm{~m}$ and $1240 \mathrm{~m}$, respectively. The Salado River basin covers $91,505 \mathrm{~km}^{2}$, and the homonymous river-more than $700 \mathrm{~km}$ long-is the most important. Its main affluents are the Las Flores and Vallimanca streams. The drainage system consists of meandering rivers partially connected to permanent and seasonal lagoons. The low regional terrain slope favors the retention and storage of rainwater for long periods, mainly in the soil, over the floodplain and in shallow lagoons.

Historically, this region was characterized by long periods of water deficit, persistent droughts and high temperatures, interspersed with periods of heavy rainfall that cause severe floods. Since grain production in the Salado River basin accounts for $30 \%$ of the national production, that of meat for $25 \%$ and the agro-industrial products of vegetal origin exceeds $60 \%$, it is evident that these natural phenomena can have a relevant impact on the national economy.

The climate of the area is temperate and humid, with warm summers and cool winters. Mean annual temperatures oscillate between $13{ }^{\circ} \mathrm{C}$ and $16{ }^{\circ} \mathrm{C}$. The temperature of the warmest month (January) ranges between $20{ }^{\circ} \mathrm{C}$ and $23{ }^{\circ} \mathrm{C}$, while that of the coldest month (July) between $7{ }^{\circ} \mathrm{C}$ and $9{ }^{\circ} \mathrm{C}$. Annual precipitation varies from $1000 \mathrm{~mm}$ in the north-eastern part of the region to $700 \mathrm{~mm}$ in the south-west. The largest precipitation events are usually generated by the contrast between the warm and humid air mass originating from the semi-permanent anticyclone over the Atlantic Ocean and the cold air mass flowing from the south-west.

The sws is the quantity of rainwater that remains over the soil surface when the water infiltration is null because the soil storage capacity is achieved. This water often cannot infiltrate because the water table is too close to the surface, and there are many depressed areas in the Pampean flatlands. Thus, vertical rainfall and evapotranspiration fluxes are more important than horizontal water movements or surface and subsurface flows in flat regions like the study area. The level of the water table is high during periods of sws, eventually rising to the surface, thereby increasing the flood potential as well as the extension of lakes, ponds and surface impoundments. Nowadays, such a situation occurs more frequently over the Pampean flatlands as a result of the increased precipitation, as the studies performed during the last decades [4-6].

According to Barros et al. [7] subtropical Argentina, Paraguay and southern Brazil recorded more precipitation during summer in the last decades of the XX century, and the interannual variability also increased. During this season, a low-level convergence area, a high-level divergence area and an 
intense convection develop in the northern part of this macro-area, forming the South Atlantic Convergence Zone (SACZ), which has a relationship with the interannual precipitation variability in the same area.

Kruse et al. [8] described the relationship between precipitation, evapotranspiration, soil water storage, sws, the water table, subsurface and surface runoff under different scenarios in the north-western BA province, finding a good temporal relationship between water table levels and sws.

Events of sws occur almost every year, regardless of the ENSO phase, but are particularly intense during the El Niño phase [9]. The differences between the rainfalls in the two ENSO phases appear most evident in the northern BA province, where they reach values of $100 \mathrm{~mm}$, suggesting that the El Niño phase seems to control the magnitude and spatial extent of the sws. In particular, the north-eastern BA reveals high risks of saturated soils and floods in general during the autumn, and in particular during the years characterized by the El Niño phase.

\section{Materials and Methods}

This section is divided in several parts related to the different sources of information and methodologies utilized in the elaborations.

Figure 1 represents the geographical location of the BA province, and reports also the reticular composition of the basin.

Figure 1. Buenos Aires province and the Salado river basin.

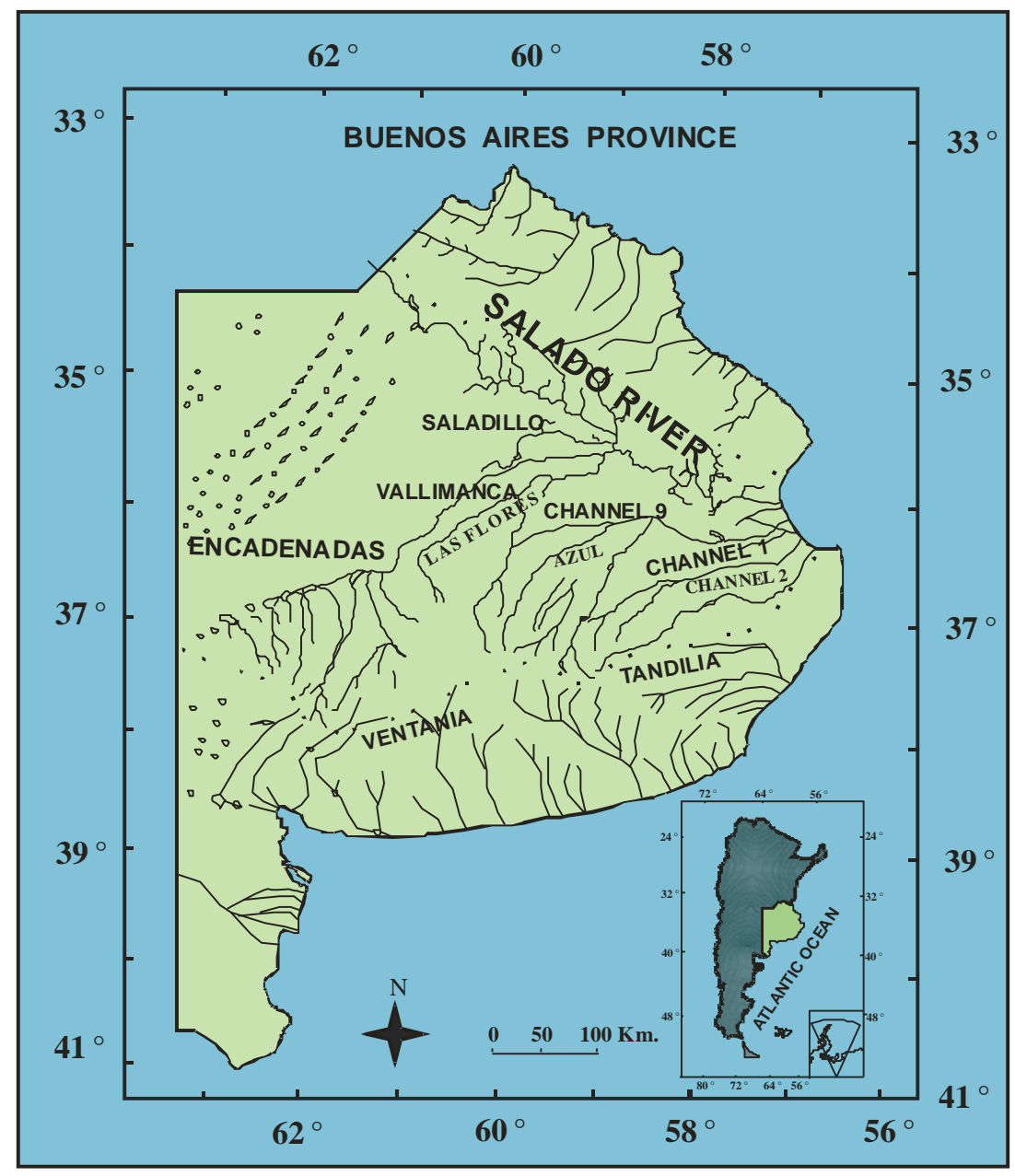




\subsection{Data and Meteorological Stations}

Daily precipitation data for the period 1968-2008 were provided by the National Meteorological Service-SMN (29 stations) and by the National Institute of Agronomic Technology-INTA (five stations). The meteorological stations were selected according to their long record, homogeneity and historical development.

Figure 2 shows the studied area and reports the position of the meteorological stations used in the work, which are listed in Table 1.

Table 1. Denomination and code of the meteorological stations used in this study.

\begin{tabular}{|llll|}
\hline Number & Station & Number & Station \\
$\mathbf{1}$ & San Pedro INTA & $\mathbf{1 8}$ & Daireaux \\
$\mathbf{2}$ & Pergamino INTA & $\mathbf{1 9}$ & Santa Teresita \\
$\mathbf{3}$ & Junín & $\mathbf{2 0}$ & Azul \\
$\mathbf{4}$ & San Miguel & $\mathbf{2 1}$ & Olavarría \\
$\mathbf{5}$ & Mariano Moreno & $\mathbf{2 2}$ & Tandil \\
$\mathbf{6}$ & Aeroparque J. Newbery & $\mathbf{2 3}$ & Villa Gesell \\
$\mathbf{7}$ & Buenos Aires & $\mathbf{2 4}$ & Coronel Suarez \\
$\mathbf{8}$ & Ezeiza & $\mathbf{2 5}$ & Laprida \\
$\mathbf{9}$ & General Villegas & $\mathbf{2 6}$ & Piguié \\
$\mathbf{1 0}$ & La Plata & $\mathbf{2 7}$ & Benito Juárez \\
$\mathbf{1 1}$ & Nueve de Julio & $\mathbf{2 8}$ & Balcarce INTA \\
$\mathbf{1 2}$ & Punta Indio & $\mathbf{2 9}$ & Bordenave INTA \\
$\mathbf{1 3}$ & Pehuajó & $\mathbf{3 0}$ & Coronel Pringles \\
$\mathbf{1 4}$ & Trenque Lauquen & $\mathbf{3 1}$ & Mar del Plata \\
$\mathbf{1 5}$ & Las Flores & $\mathbf{3 2}$ & Tres Arroyos \\
$\mathbf{1 6}$ & Bolivar & $\mathbf{3 3}$ & Bahía Blanca \\
$\mathbf{1 7}$ & Dolores & $\mathbf{3 4}$ & Hilario Ascasubi \\
& & & INTA \\
\hline
\end{tabular}

\subsection{Basic Hydrological Concepts}

The aim of this work is the evaluation of the soil water budget on a daily basis, considering the daily precipitation as input data. The daily mean potential evapotranspiration, two soil hydrologic values (the field capacity and the permanent wilting point) and the corresponding drought levels, evaluated according to the method used by $[10,11]$, were calculated for each station.

Daily sws data were thus obtained using the method of [12] which, in turn, is based on the method of Thornthwaite and Mather for evaluating the soil water balance (Equation 1) on a daily basis. The input data required are the measured precipitation and the daily mean potential evapotranspiration. The latter was estimated using the Penman-Monteith method [13]. 
Figure 2. The locations of the meteorological stations.

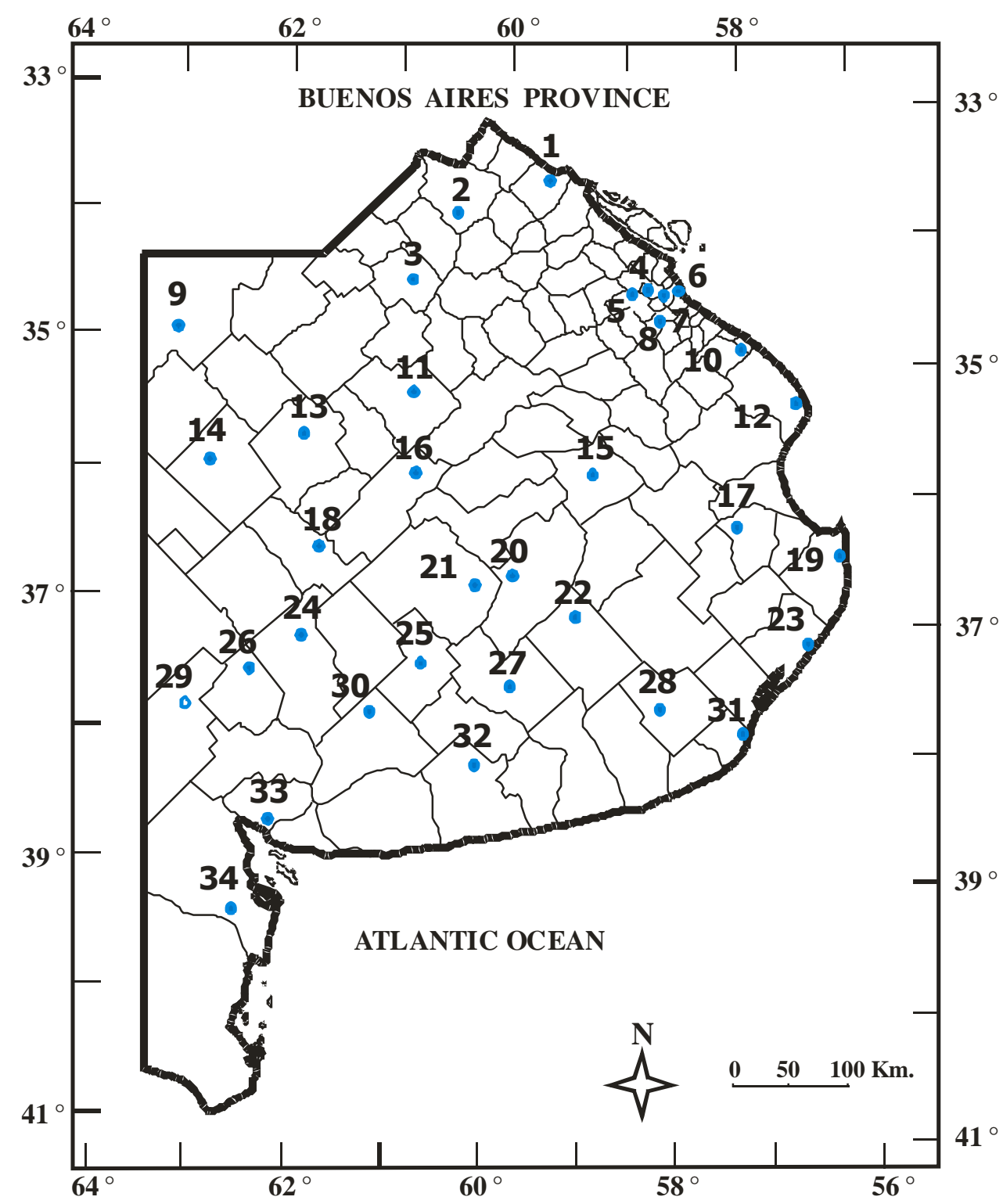

The soil water balance equation used in the model is:

$$
P P-E P+\Delta S t+S u+D e f=O
$$

where $P P$ is the daily precipitation, $E P$ the daily mean potential evapotranspiration, $\Delta S t$ the soil water storage variation, $S u$ the sws and $D e f$ the soil water deficit.

In the following step, the annual values were evaluated by summing the daily soil water balance, and were aggregated in annual areal values; thus, allowing the evaluation of the annual sws on areal basis.

The annual water balance and the sws were then analyzed in order to find the possible tendencies. As the sws values do not have normal distribution, the annual series were adjusted by using an empiric distribution of frequencies (normal cubic-root probability distribution). This operation allowed analysis of the normal distribution of the sws, calculation of the mean value relative to the studied period, and the probability of occurrence of $50 \%$ to be obtained. 


\subsection{The Salado River Basin}

The Salado river basin was considered subdivided in seven drainage areas, according to National Water Resources [14], as indicated in Table 2 and displayed in Figure 3.

Table 2. Drainage areas studied in the Buenos Aires province.

\begin{tabular}{|c|l|}
\hline Drainage area & \multicolumn{1}{|c|}{ Name } \\
\hline S1 & Northwestern area of the Salado River basin \\
\hline S2 & Central area of the Salado River basin \\
\hline \hline S3 & Salado River mouth \\
\hline S4 & Southern area of the Salado River basin and northern area of Vallimanca River basin \\
\hline S5 & Southern area of the Salado and Vallimanca Rivers basins \\
\hline \hline S6 & Western Channels area south of the Salado River \\
\hline \hline S7 & Channels area south of the Salado River \\
\hline
\end{tabular}

Figure 3. Drainage areas of the Salado River basin.

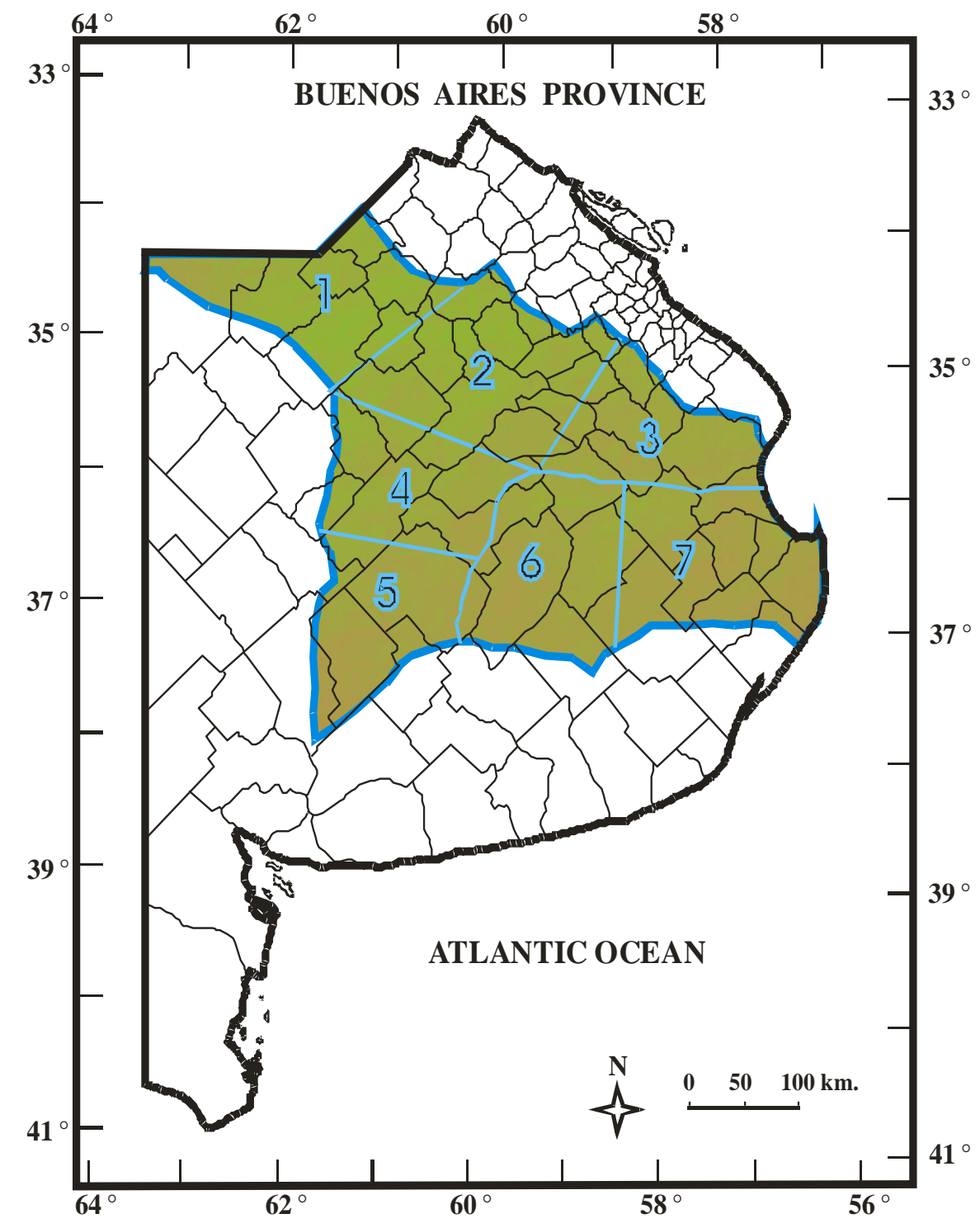




\subsection{Map Graphical Representation}

Maps showing the sws for every year of the studied period were created using the software SURFER 8.0, which allows isoline maps of the sws to be drawn.

\subsection{Soil Water Surplus}

The obtained maps allowed the spatial distribution of the annual sws to be detailed. The mean areal value was calculated for each of the drainage sub-areas mentioned in Table 2, and the sequence of these annual values of sws was used to study their temporal distribution. An annual mean areal value of $300 \mathrm{~mm}$ was considered as a threshold of sws, above which there is a relevant probability that floods can cause severe damage.

\subsection{Statistical Analysis}

The non parametric Mann-Kendall test was applied to the complete series of data. In addition, an Excel template, called MAKESENS and described in [15], was used for detecting and estimating trends in the time series of annual values of sws. This procedure is based on the nonparametric MannKendall test for the trends, and the nonparametric Sen's method for estimating the magnitude of the trend. In detail, in the first step, the Mann-Kendall test allows detection of a monotonic trend in the time series of data without seasonal or other cycles. Subsequently, the Sen's method tries to fit the data with a linear model, reported in Equation 2, where $t$ is the time expressed in years:

$$
f(t)=\mathrm{Q} t+\mathrm{B}
$$

where $\mathrm{Q}$ is the slope and $\mathrm{B}$ the offset to be determined. Finally, MAKESENS evaluates the test statistical significance using the $\alpha$ levels $0.001,0.01,0.05$ and 0.1 [16].

The Sen's method gives the following results, depending on the number of years $n$ :

- Test $Z$ for the trend assessment: if the number of samples $n$ is greater than 10 , the value of the statistic test $\mathrm{Z}$ is displayed. The absolute value of $\mathrm{Z}$ is compared to the standard normal cumulative distribution for assessing the presence of a trend at the selected significance level $\alpha$, while a positive (negative) value of $\mathrm{Z}$ indicates an upward (downward) trend.

- Statistical significance: $\alpha$ represents the smallest significance level at which the null hypothesis (absence of trends) must be rejected. If $n$ is lower than 10, the test uses the S statistic, while if $n$ is larger or equal to 10 , the test uses the $\mathrm{Z}$ (normal) statistic. To show the significance levels, the following symbols are used:

$$
\begin{array}{ll}
* * * & \text { existence of a trend with level of significance } \alpha=0.001 ; \\
* * & \text { existence of a trend with level of significance } \alpha=0.01 ; \\
* & \text { existence of a trend with level of significance } \alpha=0.05 ; \\
+ & \text { existence of a trend with level of significance } \alpha=0.1
\end{array}
$$

- Estimate with the Sen's method of the slope Q in Equation 2: Q represents the annual rate of variation of the areal sws, and is thus expressed in $\mathrm{mm} / \mathrm{year}$ :

$\mathrm{Q}_{\min }$ 99: estimate of the lower limit of $\mathrm{Q}$ with a $99 \%$ confidence interval $(\alpha=0.1)$; 
$\mathrm{Q}_{\max } 99$ : estimate of the upper limit of $\mathrm{Q}$ with a $99 \%$ confidence interval $(\alpha=0.1)$;

$Q_{\min }$ 95: estimate of the lower limit of $Q$ with a $95 \%$ confidence interval $(\alpha=0.05)$;

$Q_{\max }$ 95: estimate of the upper limit of $Q$ with a 95\% confidence interval $(\alpha=0.05)$.

- Estimate with the Sen's method of the constant B in Equation 2: B represents the mean annual areal value at the beginning of the observations, and is expressed in $\mathrm{mm}$ :

$B_{\min }$ 99: estimate of the lower limit of B with a $99 \%$ confidence interval $(\alpha=0.1)$;

$B_{\max } 99$ : estimate of the upper limit of $B$ with a $99 \%$ confidence interval $(\alpha=0.1)$;

$\mathrm{B}_{\min }$ 95: estimate of the lower limit of B with a $95 \%$ confidence interval $(\alpha=0.05)$;

$B_{\max } 95$ : estimate of the upper limit of $B$ with a $95 \%$ confidence interval $(\alpha=0.05)$;

\section{Results and Discussion}

Figure 4 shows the spatial distribution of the mean areal annual sws for two years (2001 and 2002) in which there were relevant values of sws that caused major floods in the Salado River basin.

Figure 4. Spatial distribution of the mean areal annual sws of the Salado River basin.
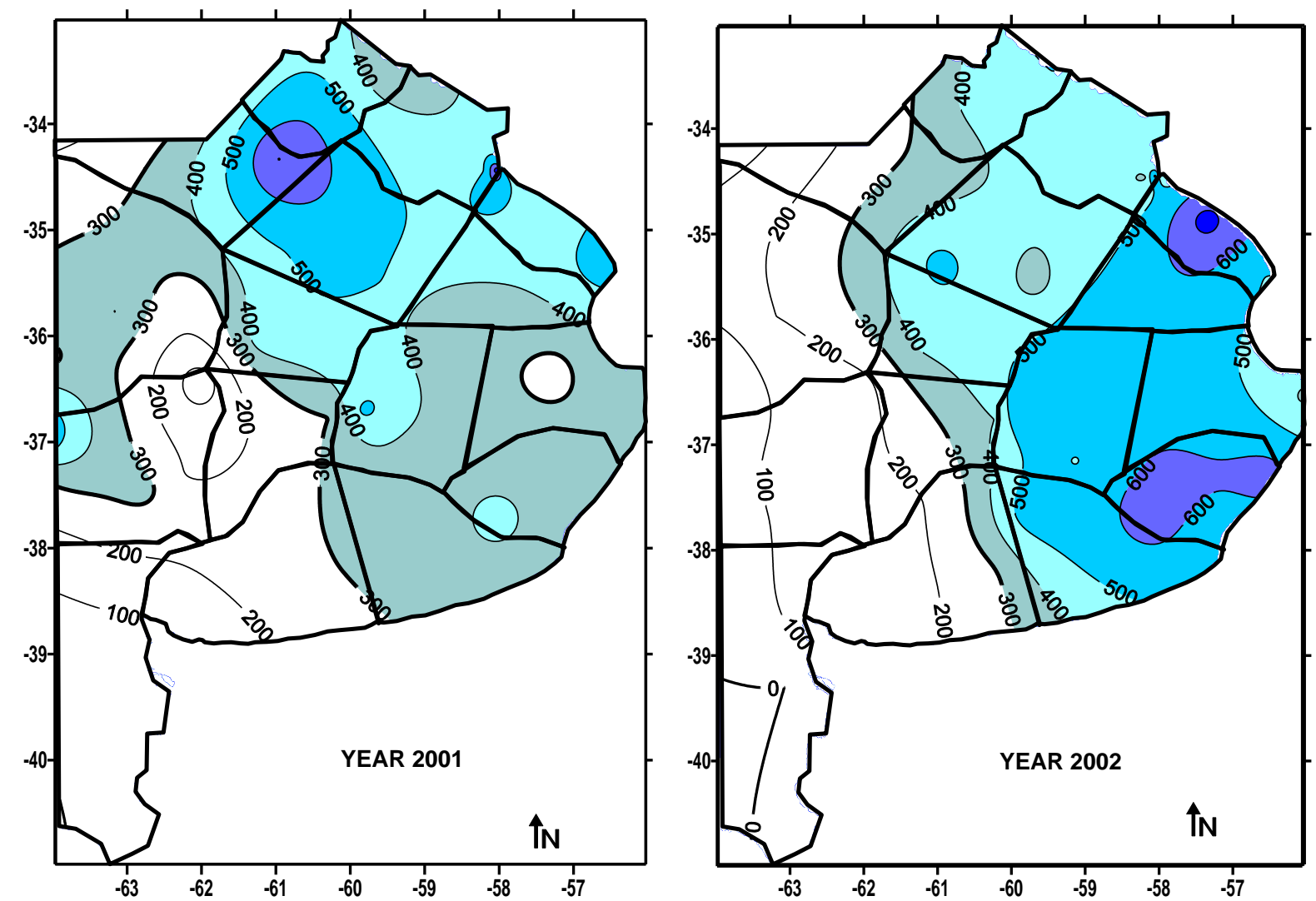

Figure 5 reports the temporal distribution of the annual mean areal values of soil, while Figure 6 shows the mean decadal values, starting from 1969, averaged over each drainage area.

The maximum value refers to the third drainage area (S3) in 1993 (600 mm), and the second maximum to the seventh drainage area in 1980. The former value is in agreement with those found by Scarpati et al. [17,18] and Gonzalez and Fernandez [2], who studied the floods of the Salado river basin. 
Figure 5. Annual distribution of soil water surplus (sws) in the seven drainage areas.

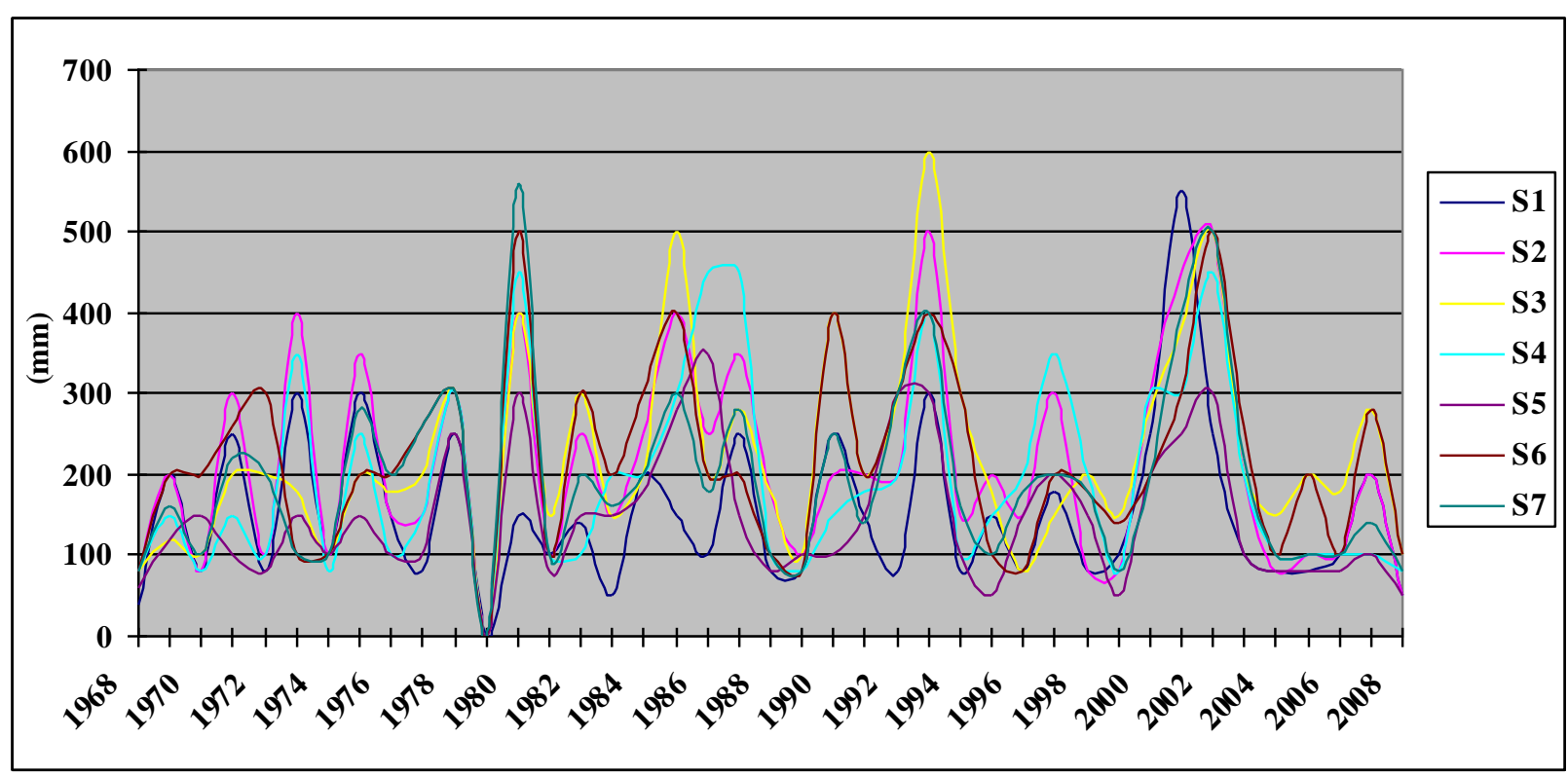

Figure 6. Mean decadal soil water surpluses of each drainage area studied.

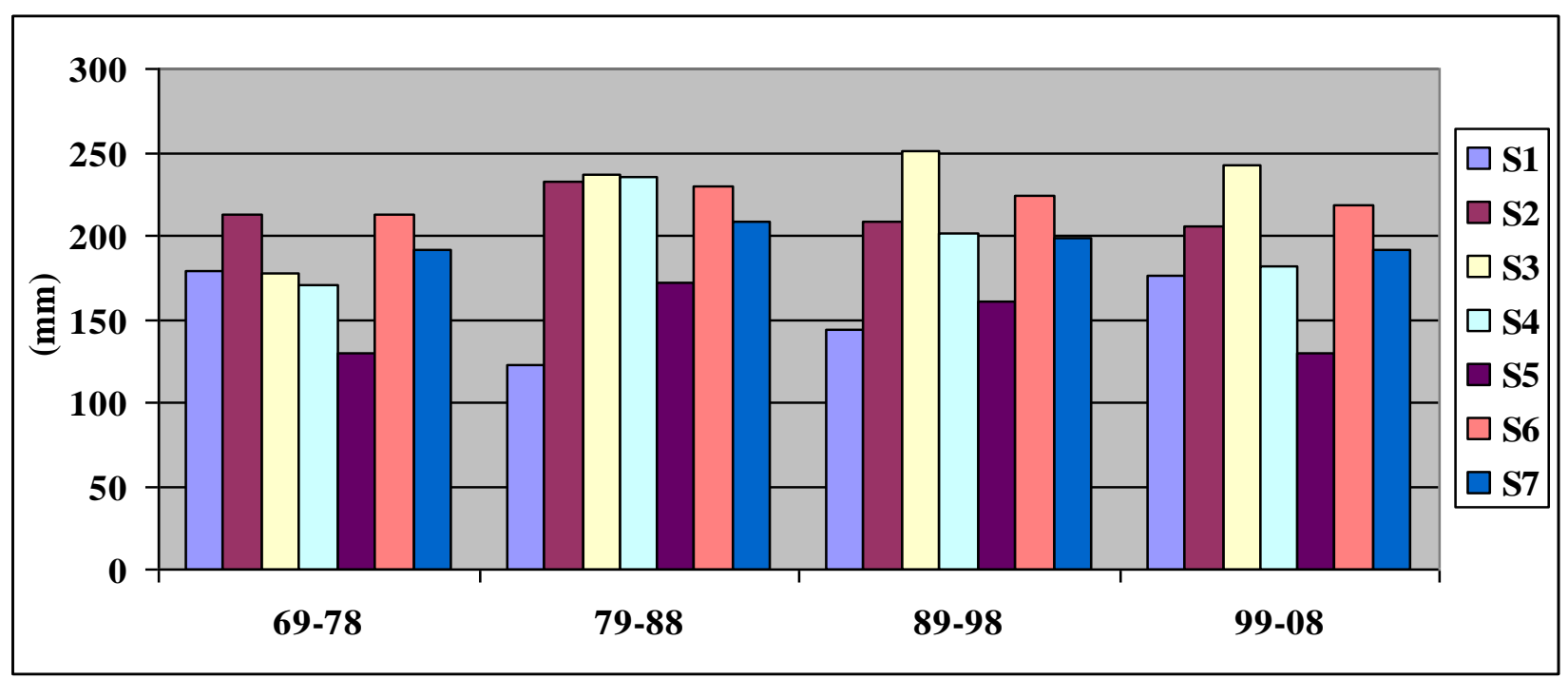

The obtained results can be summarized in this way:

1. 1968 to 1980 : the values of sws were generally small;

2. 1980 to 1995: in several years, the threshold of $300 \mathrm{~mm}$ was exceeded, including the two cases above mentioned;

3. 1995 to 1999: only the second and fourth drainage areas exceeded $300 \mathrm{~mm}$, in 1997;

4. 2000 to 2002: almost all drainage areas, except the fifth, showed large values;

5. 2003 to 2008: the sws values never reached the $300 \mathrm{~mm}$ threshold, and are very similar to the first cycle.

Figure 6, grouping the decadal values relative to all drainage areas, can exalt the different behavior of the values during the studied period, which can be summarized in the following way: 
- S1 always shows values lower than $200 \mathrm{~mm}$, and the minimum was observed during the second decade;

- S2 always shows values higher than $200 \mathrm{~mm}$, and the maximum was observed during the second decade;

- S3 shows a high value during the second decade, but the maximum corresponds to the third;

- the maxima of S4 and S5 are recorded during the second decade, and high values are also observed in the third;

- S6 and S7 values show the smallest inter-decadal variations among all drainage areas.

Table 3. Annual values of soil water surplus lower than $100 \mathrm{~mm}$ (yellow boxes), larger than $300 \mathrm{~mm}$ (orange boxes) and larger than $500 \mathrm{~mm}$ (grey boxes) for the seven drainage areas. The last column reports the number of drainage areas showing sws larger than $300 \mathrm{~mm}$. The last two lines report the number of stations in which annual sws was larger than $300 \mathrm{~mm}$ (last row) and lower than $100 \mathrm{~mm}$ (second last row).

\begin{tabular}{|c|c|c|c|c|c|c|c|c|}
\hline \multirow[t]{2}{*}{ Year } & \multicolumn{8}{|c|}{ Drainage area } \\
\hline & S1 & S2 & S3 & S4 & S5 & S6 & S7 & $\mathbf{N}$ \\
\hline 1968 & 40 & 80 & 80 & 80 & 60 & 80 & 80 & \\
\hline 1969 & 200 & 200 & 120 & 150 & 120 & 200 & 160 & \\
\hline 1970 & 80 & 80 & 100 & 80 & 150 & 200 & 100 & \\
\hline 1971 & 250 & 300 & 200 & 150 & 100 & 260 & 220 & \\
\hline 1972 & 80 & 100 & 200 & 100 & 80 & 300 & 200 & \\
\hline 1973 & 300 & 400 & 180 & 350 & 150 & 100 & 100 & 3 \\
\hline 1974 & 100 & 100 & 100 & 80 & 100 & 100 & 100 & \\
\hline 1975 & 300 & 350 & 200 & 250 & 150 & 200 & 280 & 2 \\
\hline 1976 & 150 & 150 & 180 & 100 & 100 & 200 & 200 & \\
\hline 1977 & 80 & 150 & 200 & 150 & 100 & 260 & 260 & \\
\hline 1978 & 250 & 300 & 300 & 300 & 250 & 300 & 300 & 5 \\
\hline 1979 & 0 & 0 & 0 & 0 & 0 & 0 & 0 & \\
\hline 1980 & 150 & 400 & 400 & 450 & 300 & 500 & 560 & 6 \\
\hline 1981 & 100 & 100 & 150 & 100 & 80 & 100 & 100 & \\
\hline 1982 & 140 & 250 & 300 & 100 & 150 & 300 & 200 & 2 \\
\hline 1983 & 50 & 150 & 150 & 200 & 150 & 200 & 160 & \\
\hline 1984 & 200 & 250 & 200 & 200 & 180 & 300 & 200 & 1 \\
\hline 1985 & 150 & 400 & 500 & 300 & 280 & 400 & 300 & 5 \\
\hline 1986 & 100 & 250 & 200 & 450 & 350 & 200 & 180 & 2 \\
\hline 1987 & 250 & 350 & 280 & 450 & 150 & 200 & 280 & 2 \\
\hline 1988 & 80 & 180 & 180 & 100 & 80 & 100 & 100 & \\
\hline 1989 & 80 & 100 & 100 & 80 & 100 & 80 & 80 & \\
\hline 1990 & 250 & 200 & 400 & 150 & 100 & 400 & 250 & \\
\hline 1991 & 150 & 200 & 200 & 180 & 150 & 200 & 140 & \\
\hline 1992 & 80 & 200 & 300 & 200 & 300 & 300 & 300 & 4 \\
\hline 1993 & 300 & 500 & 600 & 400 & 300 & 400 & 400 & 7 \\
\hline 1994 & 80 & 150 & 300 & 100 & 100 & 300 & 160 & 2 \\
\hline 1995 & 150 & 200 & 180 & 150 & 50 & 100 & 100 & \\
\hline
\end{tabular}


Table 3. Cont.

\begin{tabular}{|c|c|c|c|c|c|c|c|c|}
\hline \multirow{2}{*}{ Year } & \multicolumn{8}{|c|}{ Drainage area } \\
\hline & S1 & S2 & S3 & S4 & S5 & S6 & S7 & $\mathbf{N}$ \\
\hline 1996 & 80 & 150 & 80 & 200 & 150 & 80 & 180 & \\
\hline 1997 & 180 & 300 & 150 & 350 & 200 & 200 & 200 & 2 \\
\hline 1998 & 80 & 80 & 200 & 200 & 150 & 180 & 180 & \\
\hline 1999 & 100 & 80 & 150 & 80 & 50 & 140 & 80 & \\
\hline 2000 & 250 & 300 & 280 & 300 & 200 & 200 & 200 & 2 \\
\hline 2001 & 550 & 450 & 380 & 300 & 250 & 300 & 400 & 6 \\
\hline 2002 & 250 & 500 & 500 & 450 & 300 & 500 & 500 & 6 \\
\hline 2003 & 100 & 200 & 200 & 200 & 100 & 260 & 220 & \\
\hline 2004 & 80 & 80 & 150 & 100 & 80 & 100 & 100 & \\
\hline 2005 & 80 & 100 & 200 & 100 & 80 & 200 & 100 & \\
\hline 2006 & 100 & 100 & 180 & 100 & 80 & 100 & 100 & \\
\hline 2007 & 200 & 200 & 280 & 100 & 100 & 280 & 140 & \\
\hline 2008 & 50 & 50 & 100 & 80 & 50 & 100 & 80 & \\
\hline Events below $100 \mathrm{~mm}$ threshold & 19 & 13 & 7 & 16 & 20 & 12 & 13 & 100 \\
\hline Events above $300 \mathrm{~mm}$ threshold & 4 & 12 & 10 & 11 & 5 & 12 & 6 & 60 \\
\hline
\end{tabular}

Table 3 summarizes the number of years with low (lower than $100 \mathrm{~mm}$ ) and high (higher than $300 \mathrm{~mm}$ ) sws, for each drainage area. The second and sixth areas show the maximum number (12) of high sws, while the minimum value of cases is shown by the first area. Generally, there were a larger number of cases with low values of sws than with high values of sws, but this general distribution was different in the different drainage areas. For instance, the fifth and first areas show a clear prevalence of the years characterized by low sws, while the third area shows a prevalence of years with high sws.

The Mann-Kendall test revealed that the trends observed are statistically significant only for the third drainage area, at the level of $95 \%$ (Table 4).

Table 4. Statistical significance of the soil water surplus (sws) trends according to the Mann-Kendall test.

\begin{tabular}{|c|c|c|c|c|c|}
\hline \multicolumn{6}{|c|}{ Mann-Kendall test for the trend } \\
\hline $\begin{array}{l}\text { Drainage } \\
\text { area }\end{array}$ & $\mathbf{N}$ cases & & $\begin{array}{l}\text { ence } \\
=95 \%\end{array}$ & $\tau$ & Significance \\
\hline S1 & 41 & +0.213 & -0.213 & -0.015 & no \\
\hline $\mathrm{S} 2$ & 41 & +0.213 & -0.213 & -0.020 & no \\
\hline S3 & 41 & +0.216 & -0.216 & +0.185 & yes \\
\hline $\mathrm{S} 4$ & 41 & +0.213 & -0.213 & +0.061 & no \\
\hline S5 & 41 & +0.213 & -0.213 & -0.010 & no \\
\hline S6 & 41 & +0.213 & -0.213 & +0.010 & no \\
\hline S7 & 41 & +0.213 & -0.213 & -0.015 & no \\
\hline
\end{tabular}

As the results of the application of MAKESENS test were similar to those of the Mann-Kendall test, only the details relative to the only statistically significant trend, i.e., that of the third drainage area, are reported (Figure 7 and Table 5). 
Table 5. Drainage area $3(\mathrm{~S} 3)$ results for MAKESENS test.

\begin{tabular}{|c|c|}
\hline Name & $\mathrm{S} 3$ \\
\hline Test Z & 1,27 \\
\hline Significance & $>0.1$ \\
\hline $\boldsymbol{Q}$ & $1.32 \mathrm{E}+00$ \\
\hline $\mathbf{Q}_{\min } \mathbf{9 9}$ & $-1.00 \mathrm{E}+00$ \\
\hline $\mathbf{Q}_{\max } \mathbf{9 9}$ & $5.88 \mathrm{E}+00$ \\
\hline $\mathbf{Q}_{\min } \mathbf{9 5}$ & $0.00 \mathrm{E}+00$ \\
\hline $\mathbf{Q}_{\max } \mathbf{9 5}$ & $4.76 \mathrm{E}+00$ \\
\hline $\boldsymbol{B}$ & $1.70 \mathrm{E}+02$ \\
\hline $\mathbf{B}_{\min } \mathbf{9 9}$ & $2.09 \mathrm{E}+02$ \\
\hline $\mathbf{B}_{\max } \mathbf{9 9}$ & $9.18 \mathrm{E}+01$ \\
\hline $\mathbf{B}_{\min } \mathbf{9 5}$ & $2.00 \mathrm{E}+02$ \\
\hline $\mathbf{B}_{\max } \mathbf{9 5}$ & $1.14 \mathrm{E}+02$ \\
\hline
\end{tabular}

Figure 7. Trend statistics of annual soil water surplus (sws) using the Mann-Kendall test and Sen's slope.

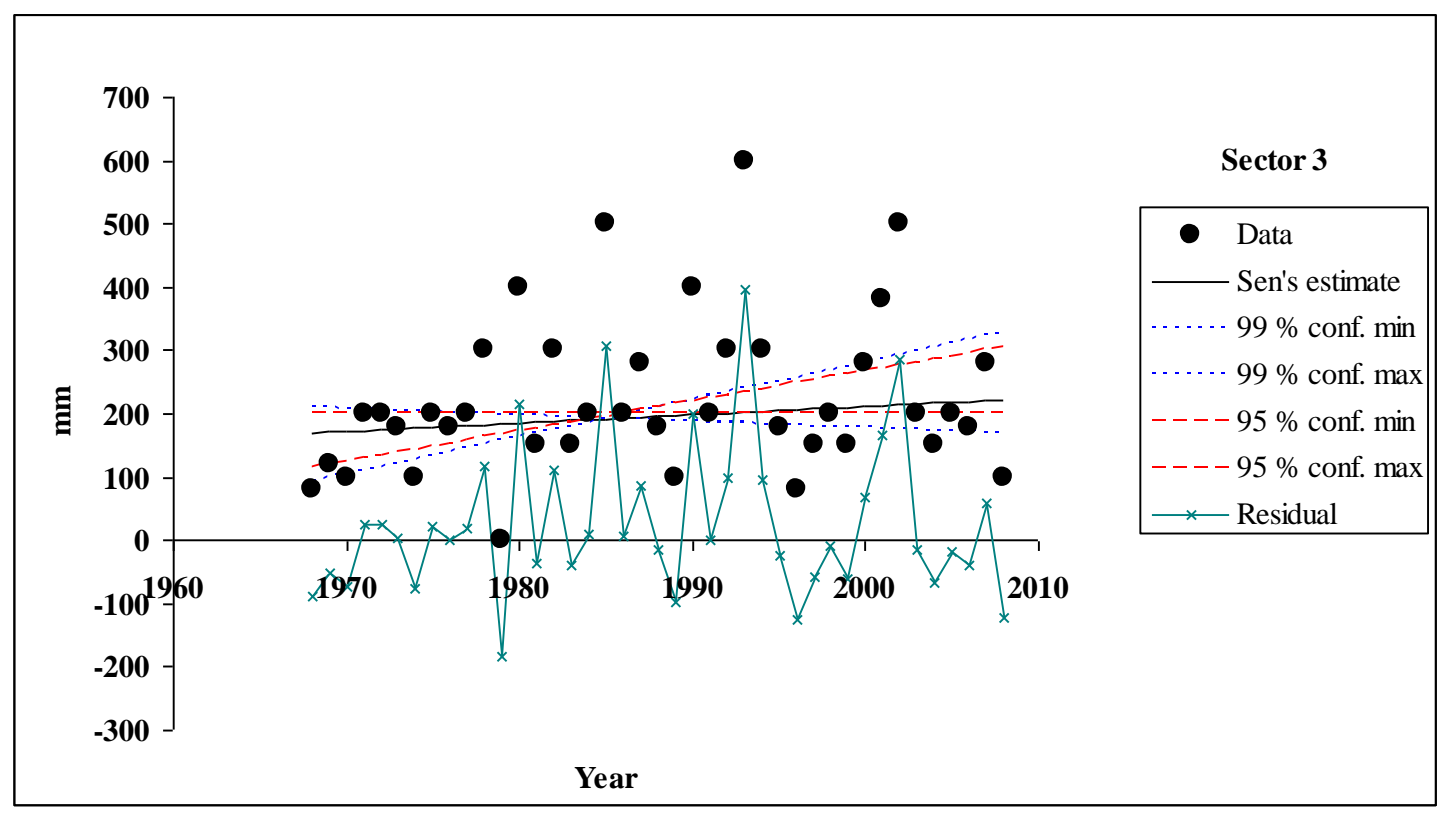

For sake of completeness, the Sen's estimates for the slope of the linear trends relative to the other drainage areas, considered non significant, are: for S1, $100 \mathrm{~mm} / \mathrm{year}$; for S2, $200 \mathrm{~mm} /$ year; for S4, $150 \mathrm{~mm} /$ year; for S5, $120 \mathrm{~mm} /$ year; for S6, $200 \mathrm{~mm} /$ year; and for S7, $180 \mathrm{~mm} /$ year. The trend of S3 area varies from 169 to $222 \mathrm{~mm} /$ year.

\section{Conclusions}

The soil water surplus relative to the period 1968-2008 was analyzed in seven drainage areas of the Salado River basin. The annual mean areal value of $300 \mathrm{~mm}$ for sws was considered as the threshold above which subsequent floods can cause damages. The maximum value present in the series of data was $600 \mathrm{~mm}$. The seven drainage areas in which the Salado River basin has been subdivided show 
different annual mean sws values, as well as a different number of events, thus the flood or drought risk differs between the different areas.

The decade 1979-1988 showed the highest values in every drainage area, except for S1 and S3. The temporal variability of the sws was evidenced by the choice of five periods related to the cycles visualized through the studied period, and they could be connected to climate change. The behavior of the sws data of drainage area 3 (Salado River mouth) is the only one with statistical significance.

As a general conclusion, an increase of the frequency of sws values above the $300 \mathrm{~mm}$ threshold in the period 1968-2008 was identified. The years 1968 and 2008 showed the smallest sws values during the whole analyzed period, and 2008 registered the worst drought in the last 40 years.

The years showing the maximum values of sws were 1983, 1985, 1993, 2001 and 2002.

The third drainage area (Salado River mouth) showed the highest sws value $(600 \mathrm{~mm})$, followed by the second area (Central area of the Salado River basin) and the seventh (Channels area south of the Salado River). The sixth area (Western Channels area south of the Salado River) registered the largest frequency of sws values higher than $300 \mathrm{~mm}$ (12 events).

Since 1980, the sws values experienced important fluctuations. An increasing tendency during the last years is observed and it is coherent with the increase in precipitation.

\section{References and Notes}

1. Forte Lay, J.A.; Quintela, R.M.; Scarpati, O.E. Variación de las características hidrometeorológicas de la llanura pampeana argentina. In Proceedings of the Memoria Encuentro Meteo 92 (Asociación Meteorológica Española), Salamanca and Cáceres, Spain, July 1992; Volume II, pp. 142-146.

2. González, M.H.; Fernández, A.E. Floods increasing in Buenos Aires Salado River Basin. In Environmental Change and Rational Water Use; Scarpati, O.E., Jones, J.A.A., Eds.; International Geographical Unión: Buenos Aires, Argentina, 2007; pp. 96-113.

3. Quintela, R.M.; Forte Lay, J.A.; Scarpati, O.E. Modification of the water resources characteristics of the Argentine's Pampean subhumid-dry region. In Proceedings of the 19th Conference on Agricultural \& Forest, 9th Conference on Biometeorology and Aerobiology (19th AGMET), Miami, FL, USA, July 1989; J-30-J-35.

4. Castañeda, M.; Barros, V. Las tendencias de la precipitación en el cono sur de América al este de los Andes. Meteorológica 1994, 21, 23-32.

5. Minetti, J.; Vargas, W. Trends and jumps in the annual precipitation en South America on the $15^{\circ}$ S. Atmósfera 1997, 11, 204-221.

6. Rusticucci, M.; Penalba, O. Interdecadal changes in the precipitation seasonal cycle over Southern South America and their relationship with surface temperature. Clim. Res. 2000, 16, 1-15.

7. Barros, V.; Gonzalez, M.; Liebmann, B.; Camilloni, I. Influence of the South Atlantic convergence zone and South Atlantic sea surface temperature on interannual summer rainfall variability in South-Eastern South America. Theor. Appl. Clim. 2000, 67, 123-133.

8. Kruse, E.; Forte Lay, J.A.; Aiello, J.L.; Basualdo, A.; Heinzenknecht, G. Hydrological processes on large flatlands: Case study in the northwest region of Buenos Aires Province (Argentina). IAHS 2001, 267, 531-535.

9. Scarpati, O.E.; Forte Lay, J.A.; Capriolo, A.D. Soil water surplus and ENSO events during the last humid period in Argentine Pampean Flatlands. Int. J. Water. 2009, 5, 181-193. 
10. Forte Lay, J.A.; Spescha, L.B. Método para la estimación de la climatología del agua edáfica en las provincias pampeanas de la Argentina. RADA 2001, 1, 67-75.

11. Forte Lay, J.A.; Scarpati, O.E.; Spescha, L.B.; Capriolo, A.D. Drought risk in the pampean region using soil water storage analysis. In Environmental Change and Rational Water Use; Scarpati, O.E., Jones, J.A.A., Eds.; International Geographical Unión: Buenos Aires, Argentina, 2007; pp. 146-168.

12. Forte Lay, J.A.; Scarpati, O.E.; Capriolo, A.D. Precipitation variability and soil water content in pampean flatlands (Argentina). Geofísica Inter. 2008, 47, 341-354.

13. Allen, R.G.; Pereira, L.S.; Raes, D.; Smith, M.; Irrigation and drainage. Crop EvapotranspirationGuidelines for Computing Crop Water Requirements; FAO: Rome, Italy, 2004; Paper 56, p. 301.

14. Atlas digital de los recursos hídricos superficiales de la República Argentina; National Water Resources: Buenos Aires, Argentina, 2002; Available online: http://www.hidricosargentina. gov.ar/CartAct.html\#1 (accessed on 18 January 2011).

15. Salmi, T.; Mata, A.; Anttila, P.; Ruoho-Airola, T.; Amnell, T. Detecting Trends of Annual Values of Atmospheric Pollutants by the Mann-Kendall Test and Sen's Slope Estimates-The Excel Template Application MAKESENS; In Publications on Air Quality; Ilmatieteen laitos Meteorologiska Institutet, Finnish Meteorological Institute Painopaikka: Edita Oyj, Helsinki, Finland, 2002.

16. Liu, S.; Mo, X.; Zhao, W.; Naeimi, V.; Dai, D.; Shu, C.; Mao, L. Temporal variation of soil moisture over the Wuding River basin assessed with an eco-hydrological model, in-situ observations and remote sensing. Hydrol. Earth Syst. Sci. 2009, 13, 1375-1398.

17. Scarpati, O.E.; Spescha, L.B.; Capriolo, A.D. The impact of the heavy floods in the Salado River basin, Buenos Aires province, Argentina. Mitigation Adaptation Strateg. Glob. Change 2002, 7 , 285-301.

18. Scarpati, O.E.; Forte Lay, J.A.; Fernandez Long, M.E.; Capriolo, A.D. ENSO influence on soil water balance and temperature in pampean flatlands (Argentina) with special analysis to San Pedro area. In Environmental Change and Rational Water Use; Scarpati, O.E., Jones, J.A.A., Eds.; International Geographical Unión: Buenos Aires, Argentina, 2007; pp. 169-183.

(C) 2011 by the authors; licensee MDPI, Basel, Switzerland. This article is an open access article distributed under the terms and conditions of the Creative Commons Attribution license (http://creativecommons.org/licenses/by/3.0/). 